\title{
The Long-Term Stability of Triglyceride Molecules in Adipose Tissue *
}

\author{
ENOCH GoRdIS $\dagger$ \\ (From The Rockefeller Institute, New York, N. Y.)
}

During transport of triglycerides from intestine to blood and from blood to adipose tissue, hydrolysis and re-esterification take place. The experiments reported here were done to determine whether triglycerides in adipose depots are continually hydrolyzed and their fatty acids re-esterified, or whether triglyceride molecules, once deposited, remain intact in storage until mobilized.

Hollenberg studied this question (1) by exteriorizing the epididymal fat pads of living rats according to the method of Stein and Stein (2) and immersing the pads, with their blood supply intact, into a solution of palmitic acid- ${ }^{14} \mathrm{C}$. The pads were then replaced within the animal, and the operative wound was closed. The distribution of the labeled palmitate between the more saturated and less saturated glycerides was studied both shortly after the immersion and 2 weeks later. Little exchange of the isotope between the two glyceride groups was found after 2 weeks. In the studies reported here, rats were fed in sequence fats of widely differing fatty acid compositions. Adipose tissue was then analyzed in order to detect those triglycerides that could have been formed only by interesterification within adipose stores. The evidence indicated that little exchange of triglyceride fatty acids occurred in storage even after 2 months.

\section{Methods}

Triglycerides were separated according to their degree of unsaturation by the thin layer chromatographic method

\footnotetext{
* Submitted for publication July 2, 1965; accepted August 19, 1965.

Supported by U. S. Public Health Service grant 03963-05.

Presented in part at the combined meeting of the American Society for Clinical Investigation and the American Federation for Clinical Research, Atlantic City, N. J., May 1965. Abstracted in J. clin. Invest. 1965, 44, 1055.

$\dagger$ Address requests for reprints to Dr. Enoch Gordis,
} The Rockefeller Institute, New York, N. Y. 10021. of Barrett, Dallas, and Padley (3), as modified by Kaufmann and Wessels (4). A slurry prepared from 70 $\mathrm{g}$ of silica gel $\mathrm{G}$ and $140 \mathrm{ml}$ of $12 \frac{1}{2} \%$ aqueous silver nitrate solution was spread as a layer $700 \mathrm{~m} \mu$ thick on two plates of $20 \times 40 \mathrm{~cm}$. The lipid sample, weighing up to $80 \mathrm{mg}$, was applied in petroleum ether solution along a line parallel to the short edge of the plate, and the plate was developed by ascending chromatography in benzene-ethyl ether 85:15 ( $\mathrm{vol} / \mathrm{vol})$. The solvent front reached a level about $2 \mathrm{~cm}$ below the top of the plate in 5 hours. The separated glycerides appeared as yellow bands in ultraviolet light after the plates were sprayed with $0.3 \%$ dichlorofluorescein in methanol. Appropriate bands were scraped from the plate with a razor blade, and the scrapings packed into columns at the bottom of which a small amount of activated silicic acid ${ }^{1}$ had been placed to trap the fluorescein. The triglycerides were eluted with $30 \mathrm{ml}$ of ethyl ether. The eluants were extracted with water to remove silver nitrate and dried over sodium sulfate. The solvent was evaporated from each sample, and lipid residues were then either transmethylated by the method of Stoffel, Chu, and Ahrens (5) for gas chromatography of fatty acids, or hydrolyzed with pancreatic lipase to determine the fatty acids esterified at the middle glycerol carbons.

Hydrolysis of triglycerides with pancreatic lipase was performed by the method of Mattson and Volpenhein (6) as modified by Luddy and co-workers (7) for the analysis of samples weighing 5 to $10 \mathrm{mg}$. Hydrolysis was stopped by extracting the reaction mixture in 20 vol of chloroform-methanol $2: 1$ ( $\mathrm{vol} / \mathrm{vol})$. The solution was filtered, and 0.2 vol of $0.15 \mathrm{M}$ saline was added to the filtrate. The phases were split, and the lipid was recovered by evaporating the chloroform phase. The residue was dissolved in petroleum ether (bp $30^{\circ}$ to $60^{\circ} \mathrm{C}$ ) and chromatographed on thin-layer plates of unmodified silica gel $\mathrm{G}$ with the solvent di-isopropyl ether-acetic acid 100:1 ( $\mathrm{vol} / \mathrm{vol}$ ). The bands containing the monoglycerides were scraped off with a razor blade. The monoglycerides were transmethylated for gas chromatography of fatty acids by refluxing the silicic acid scrapings in dry $\mathrm{HCl}$-methanol according to the method of Stoffel and associates (5).

The possibility of contamination of the monoglycerides by monoglycerides derived from fat in the lipase powder was excluded, since no monoglyceride band was seen after thin-layer chromatography of the extract of a reaction blank (lipase powder, buffer solution, without triglyceride substrate). As an additional check, the fat extracted

\footnotetext{
1 Bio-Rad Laboratories, Richmond, Calif.
} 
from $2 \mathrm{~g}$ of lipase powder was hydrolyzed with pancreatic lipase. The monoglyceride fatty acids were limited almost entirely to saturated acids. These acids were not found during the experimental analysis of oleodilinoleins described below.

Gas chromatography of fatty acid methyl esters was performed on a 6 -foot column packed with $17 \%$ ethylene glycol succinate polyester on Chromosorb-W. ${ }^{2}$ Effluents were detected with a strontium-90 ionization detector calibrated with appropriate standard mixtures. ${ }^{2}$

Solvents were reagent grade, redistilled before use. Silica gel $\mathrm{G}$ contained $13 \%$ calcium sulfate as binder; 3 crude porcine pancreatic lipase 4 was used.

Male rats of the Sprague-Dawley strain weighing about $100 \mathrm{~g}$ were fed diets containing $45 \%$ fat. ${ }^{5}$ Diets were prepared for these experiments by the addition of appropriate amounts of coconut oil, safflower oil, or triolein to the standard "fat free" diet. The fatty acid compositions of coconut oil and safflower oil are listed in Table I.

Rats were killed by decapitation, and the epididymal fat pads were homogenized in chloroform-methanol $2: 1$ (vol/vol). The homogenates were filtered, extracted with 0.2 vol of $0.15 \mathrm{M}$ saline, and the chloroform phases evaporated. Lipid residues were dissolved in petroleum ether (bp $30^{\circ}$ to $60^{\circ} \mathrm{C}$ ) for chromatography on $\mathrm{AgNO}_{3}$ impregnated silica gel $\mathrm{G}$.

Nomenclature. Triglycerides of different degrees of unsaturation are symbolized by a triad of digits, each digit representing the number of double bonds in a constituent fatty acid. Positional isomers are distinguished by the use of upper bars, and triglyceride groups as a whole, without regard for fatty acid position, are represented by the three digits enclosed in square brackets. For example, [122] represents all the oleodilinoleins, whereas the isomers 1-oleodilinolein and 2-oleodilinolein are represented by $\overline{122}$ and $\overline{212}$, respectively. Positional isomers within a triglyceride group are not resolved by chromatography on $\mathrm{AgNO}_{3}$-impregnated silica gel, but the isomer proportions within a group may be determined by pancreatic lipase

${ }^{2}$ Applied Science Laboratories, State College, $\mathrm{Pa}$.

3 E. Merck, A. G., Darmstadt, Germany.

4 Mann Research Laboratories, New York, N. Y.

5 Supplied by Nutritional Biochemicals, Cleveland, Ohio.
TABLE I

Fatty acid compositions of coconut oil and safflower oil*

\begin{tabular}{lcccccc}
\hline & $12: 0$ & $14: 0$ & $16: 0$ & $18: 0$ & $18: 1$ & $18: 2$ \\
\hline & & \multicolumn{5}{c}{ mass \% } \\
Coconut oil & 45.5 & 25.4 & 12.3 & 4.0 & 10.3 & 2.4 \\
Safflower oil & & & 5.1 & 1.8 & 10.2 & 82.6 \\
\hline
\end{tabular}

* Fatty acids of 12 carbons or longer were determined. Coconut oils may contain up to $10 \%$ of fatty acids of 10 carbons or less.

hydrolysis of eluted triglycerides. During chromatography on $\mathrm{AgNO}_{3}$-impregnated silica gel $\mathrm{G}$, certain groups of triglycerides are resolved into subgroups. For example, triglycerides containing four double bonds are resolved into the [022] and [112] groups (4). The former may contain both $\overline{022}$ and $\overline{202}$, the latter both $\overline{112}$ and $\overline{121}$. Similar subdivisions occur with other more saturated glycerides. Those designated on the figures have been identified by gas chromatography of fatty acids derived from eluted triglycerides.

\section{Results}

Adipose tissue glycerides after feeding either coconut oil or safflower oil. Rats weighing about $100 \mathrm{~g}$ were fed for 6 weeks a diet containing coconut oil as the sole source of fat. This was done to determine whether the glyceride pattern of dietary fat would be maintained in adipose tissue, or whether the predominant adipose glycerides would be of intermediate saturation, formed by interesterification of endogenous and dietary fatty acids. Table II lists the fatty acid compositions of adipose tissue triglycerides from rats fed coconut oil for 6 weeks. In Figure 1, the glyceride patterns of the dietary fat and of the adipose tissue that resulted from feeding it are compared. Coconut oil is a highly saturated fat, and the adipose tissue of rats fed this oil contained only highly saturated glycerides. The adipose tissue did not contain appreci-

TABLE II

Fatty acid compositions of adipose tissue triglycerides from rats fed either coconut oil or safflower oil or both in sequence

\begin{tabular}{|c|c|c|c|c|c|c|c|}
\hline \multirow[b]{2}{*}{ Dietary fat } & \multicolumn{7}{|c|}{ Fatty acids } \\
\hline & $12: 0$ & $14: 0$ & $16: 0$ & $16: 1$ & $18: 0$ & $18: 1$ & $18: 2$ \\
\hline & \multicolumn{7}{|c|}{ mass $\%$} \\
\hline Coconut oil, 6 weeks & 30.3 & 17.4 & 19.7 & 3.4 & 6.0 & 23.1 & Trace \\
\hline Safflower oil, 6 weeks & & Trace & 7.7 & Trace & 2.4 & 12.8 & 77.0 \\
\hline $\begin{array}{l}\text { Coconut oil, } 3 \text { weeks; } \\
\text { safflower oil, } 3 \text { weeks }\end{array}$ & 12.4 & 6.5 & 14.4 & 1.4 & 3.0 & 16.6 & 45.6 \\
\hline $\begin{array}{l}\text { Coconut oil, } 3 \text { weeks; } \\
\text { safflower oil, } 3 \text { weeks; } \\
\text { triolein, } 5 \text { weeks }\end{array}$ & 2.6 & 2.7 & 8.0 & 2.7 & 1.2 & 66.4 & 16.4 \\
\hline
\end{tabular}




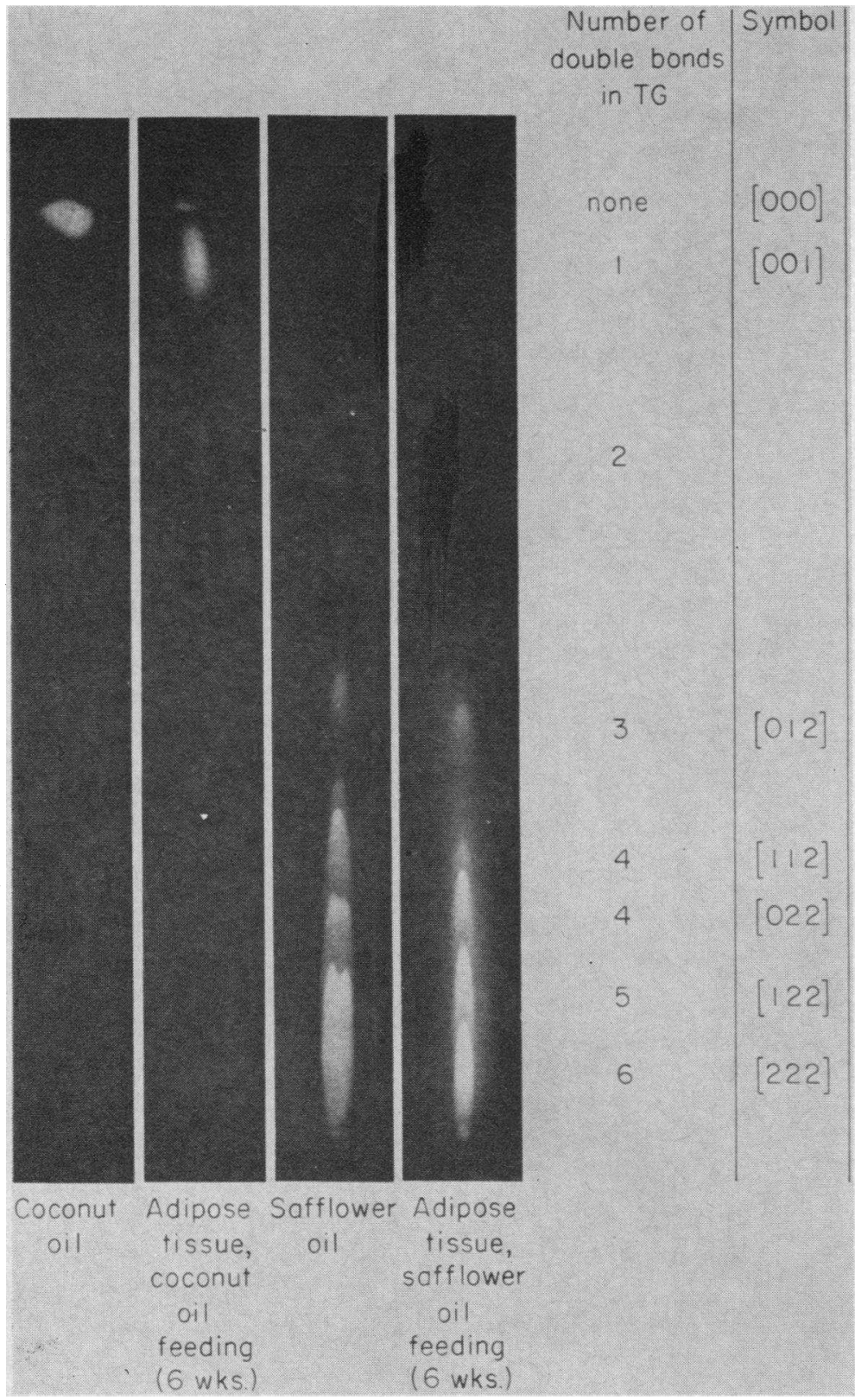

Fig. 1. The TRIGLYCerides (TG) OF COCONUT OIL, SAFFLOWER OIL, AND THE ADIPOSE TISSUE THAT RESULTED FROM FEEDING EACH. Ascending thinlayer chromatography on $\mathrm{AgNO}_{3}$-impregnated silica gel $\mathrm{G}$. The solvent was benzene-ethyl ether 85:15 (vol/vol). Saturated triglycerides move more rapidly than unsaturated triglycerides. The pattern of glycerides laid down in adipose tissue after feeding coconut oil or safflower oil resembled that of the fed fat.

able amounts of glycerides of intermediate degree of saturation. Similarity in the glyceride patterns of dietary and adipose triglycerides was also noted when a group of rats were fed safflower oil as the sole fat for 6 weeks. Table II lists the fatty acid compositions of the adipose tissue triglycerides from rats fed safflower oil for 6 weeks. This highly unsaturated oil consists largely of glycerides 
of 4,5 , and 6 double bonds, and this pattern was seen in the adipose tissue as well. Again, the adipose tissue did not contain significant amounts of glycerides of intermediate degree of saturation (Figure 1).
The glycerides of adipose tissue after feeding coconut oil and safflower oil in sequence. The next study was done to determine whether triglycerides, once deposited in adipose tissue, are continually hydrolyzed and re-esterified. Five

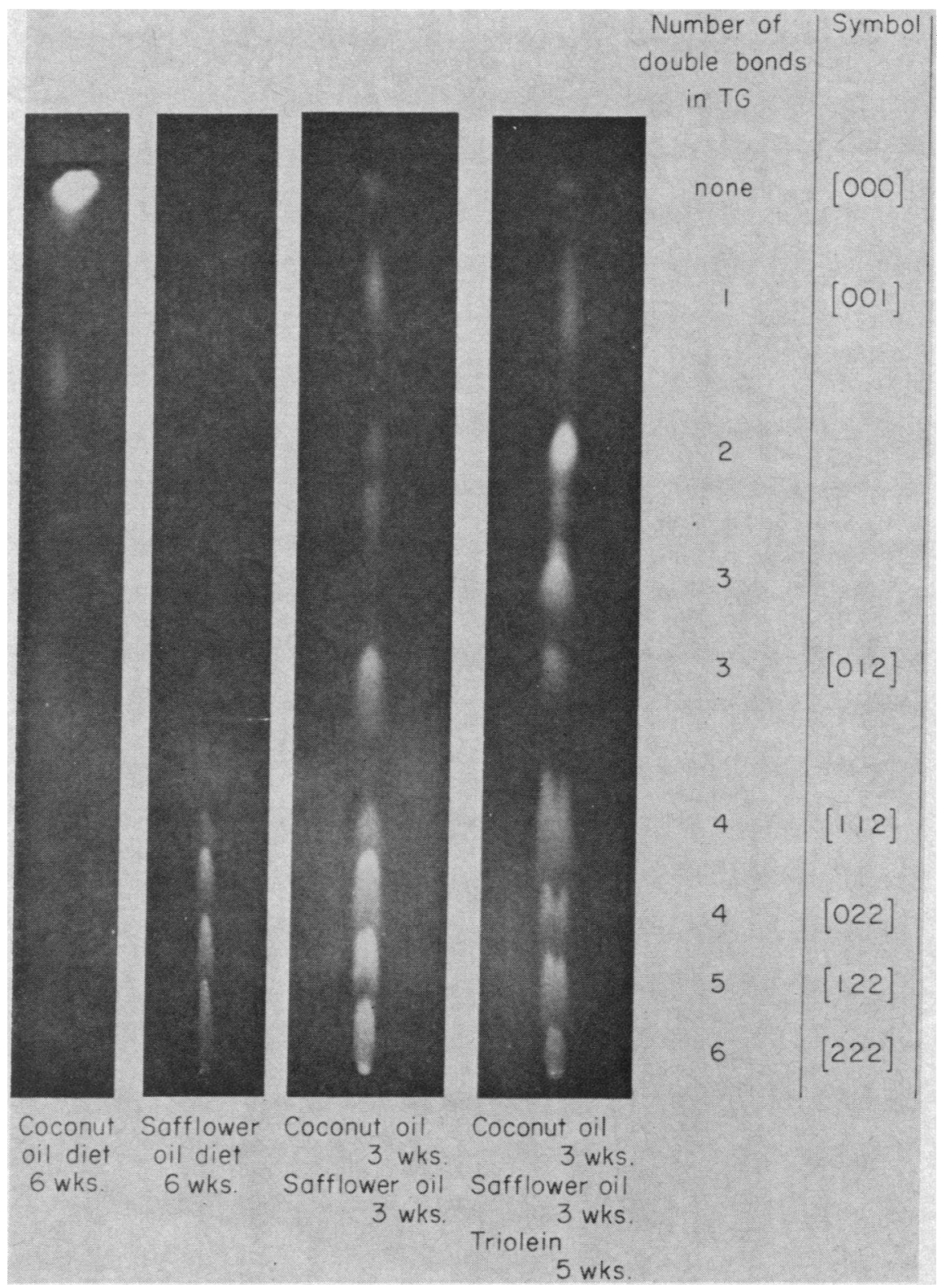

Fig. 2. The tRIGLYCERIDES OF Adipose tisSUe AFTER FEEDING COCONUT OIL, SAFFLOWER OIL, BOTH OILS IN SEQUENCE, AND BOTH OILS IN SEQUENCE FOLLOWED BY TRIOLEIN. Chromatography as in Figure 1 . When oils were fed in sequence, the mixture of triglycerides in adipose tissue resembled the one that would result from mixing the oils in vitro without interesterification. The extent of interesterification in vivo was determined from the compositions of [022] and [122] triglycerides. 
rats, each weighing about $100 \mathrm{~g}$, were fed a diet containing coconut oil as the sole fat for the first 3 weeks, safflower oil as the sole fat for the next 3 weeks, then triolein as the sole fat for the final 9 weeks. Coconut oil is rich in lauric $(12: 0)$ and myristic (14:0) acids, whereas safflower oil contains about $80 \%$ linoleic acid $(18: 2)$. Lauric and myristic acids are not present in safflower oil, and linoleic acid is absent from coconut oil. None of these acids is synthesized to a significant degree in adipose tissue (8). Epididymal fat was obtained from one rat at 6 weeks, and from additional rats at $7,8,12$, and 15 weeks. Figure 2 shows that the pattern of glycerides seen in adipose tissue after feeding coconut oil and safflower oil resembles the one that would be seen after mixing the oils in vitro without interesterification. Table II lists the fatty acid compositions of the adipose tissue triglycerides displayed in Figure 2.

From each adipose sample two groups of glycerides were isolated by chromatography on $\mathrm{AgNO}_{3}$ silica gel $\mathrm{G}$ :

1) [022] triglycerides (monosaturated dilinoleins). This group of glycerides is found in safflower oil, not in coconut oil. Any incorporation of lauric or myristic acids into this group of glycerides must have resulted from exchange of fatty acids between triglycerides derived from the two dietary fats. The fatty acid composition of [022] glycerides cannot be affected by feeding triolein, since this group contains no monoenoic acids. In Figure 3 is plotted the ratio of short-chain to total saturated acids for the whole adipose triglyceride and for the [022] glycerides. At 6 weeks, the ratio was 0.51 in the whole adipose triglyceride, but only 0.14 in the [022] glycerides. During the final 9 weeks, little further penetration of shortchain acids into this group occurred.

2) [122] triglycerides (oleodilinoleins). The ratio of the isomers $\overline{212}$ to $\overline{122}$ in this group was determined by pancreatic lipase hydrolysis of the [122] glycerides. The expected values for this ratio were computed two ways: for a random interesterification of the total adipose triglyceride, and according to Vander Wal's distribution theory (9), which accounts for the actual distribution of fatty acids on the central glycerol carbon. The latter calculation was based on results of pancreatic lipase hydrolysis of the whole adipose triglyceride. In Figure 4, the expected and observed values for the isomer ratio $\overline{122} / \overline{212}$ are compared. The stability of the isomer ratio in the [122] triglycerides indicates that this group did not undergo extensive interesterification in adipose tissue stores.

The glycerides of adipose tissue after feeding a mixture of coconut oil, safflower oil, and triolein. A control group of five rats was fed the three oils together for 6 weeks, then triolein alone for the final 9 weeks. Figure 5 shows that when the oils were fed together rather than in sequence, a con-

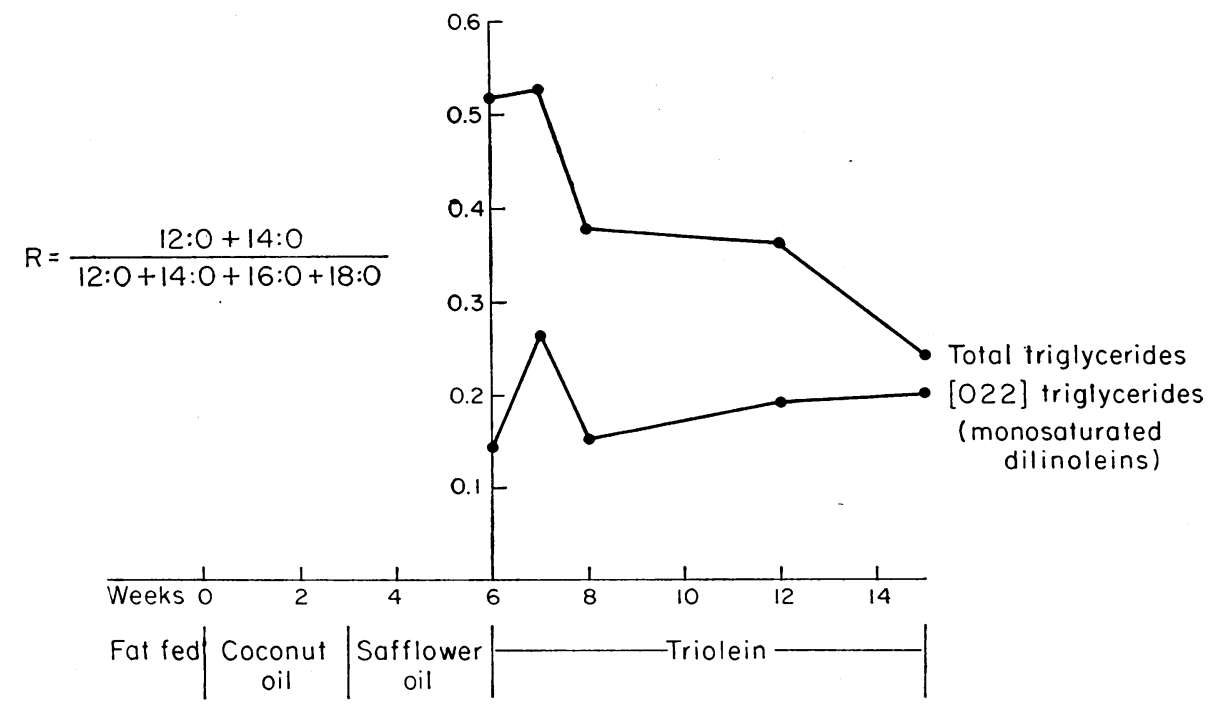

Fig. 3. LACK OF TURNOVER WITHIN ADIPOSE TISSUE TRIGLyCERIDES. Note the failure of shortchain fatty acids to penetrate the [022] triglycerides (monosaturated dilinoleins). $\mathrm{R}=$ ratio. 


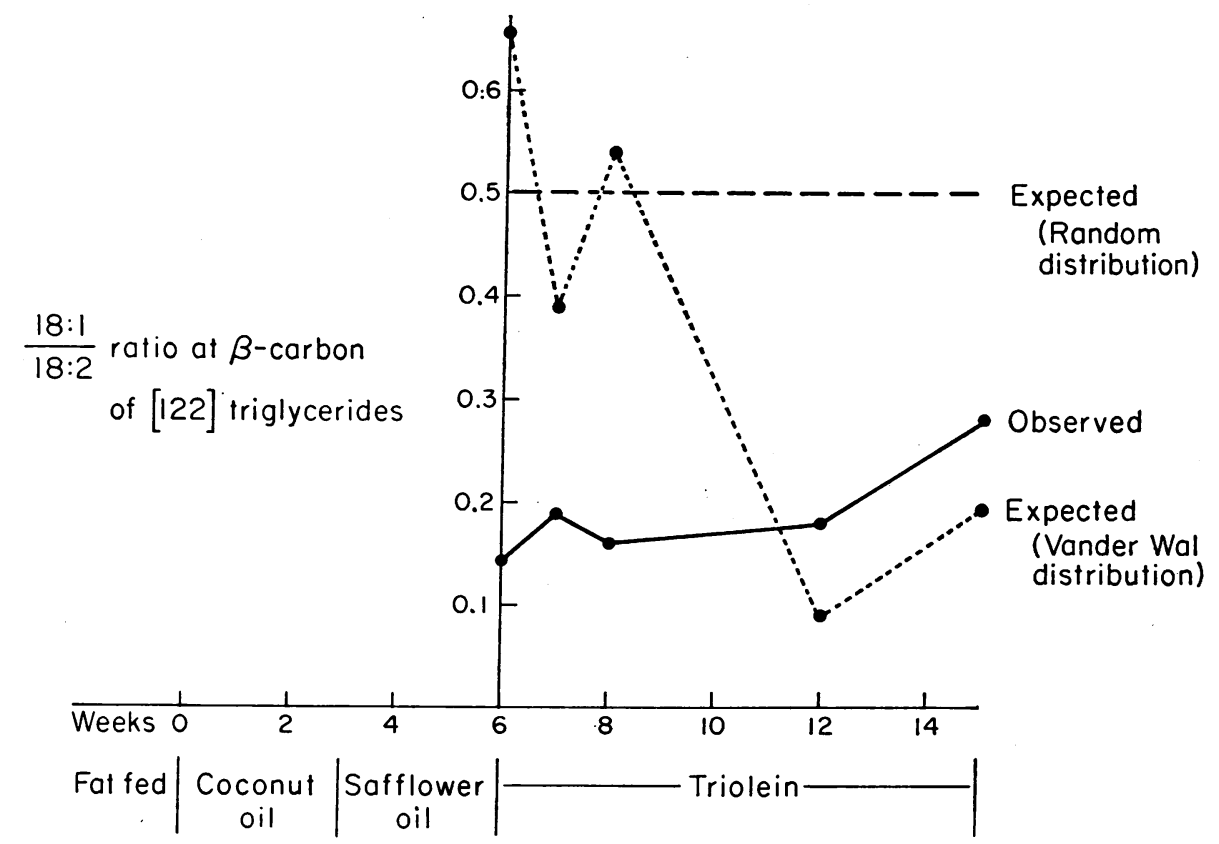

Fig. 4. LACK OF TURNOVER WITHIN ADIPOSE TISSUE TRIGLYCERIDES. Note the stability of isomer ratio of [122] glycerides (oleodilinoleins).

siderable amount of short-chain acids penetrated glycerides containing short-chain saturated acids the [022] glycerides before deposit.

An additional finding, seen in both Figure 3 and Figure 5 , is that during the triolein feedings, triwere.lost more rapidly from adipose tissue than triglycerides containing long-chain saturated acids. Similar observations were reported by Longen-

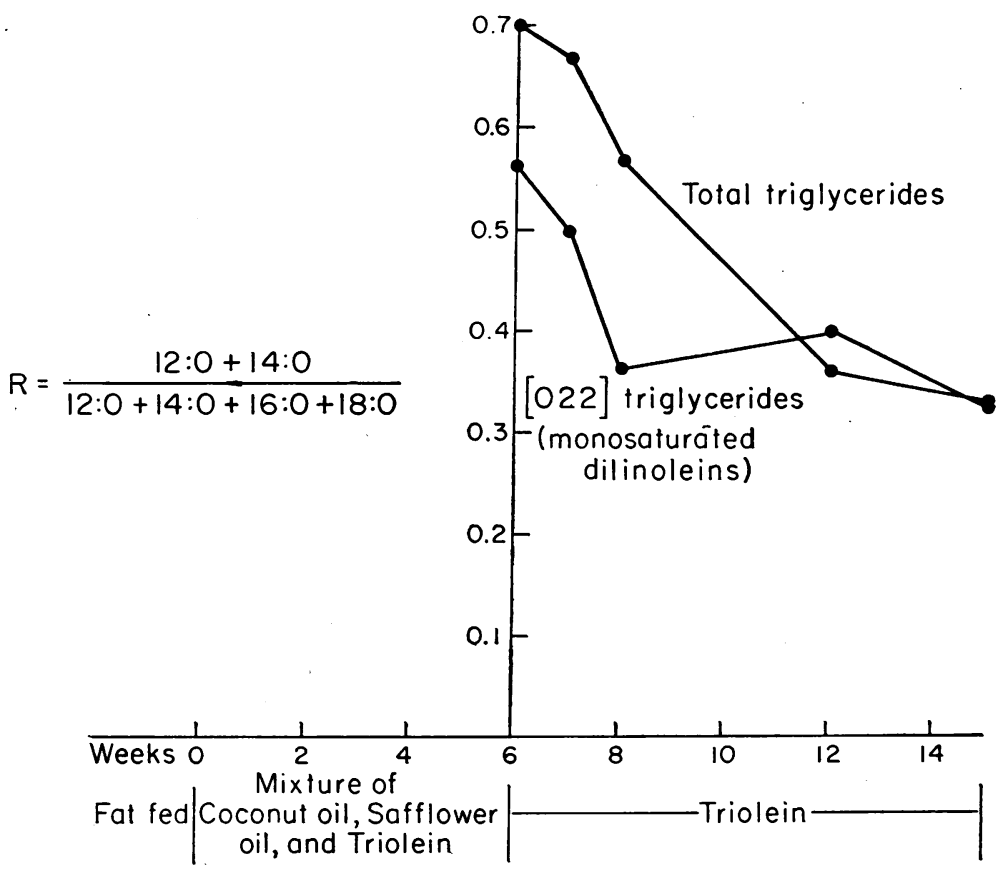

FIG. 5. INTERESTERIFICATION OF TRIGLYCERIDES BEFORE DEPOSIT IN ADIPOSE TISSUE WHEN OILS WERE FED TOGETHER RATHER THAN IN SEQUENCE. 
ecker (10). In that study, rats were fed coconut oil for 2 weeks, then fasted. During the fast, lauric and myristic acids disappeared from adipose tissue more rapidly than palmitic acid.

\section{Discussion}

When rats were given a diet containing both fat and carbohydrate without restriction, little exchange of fatty acids among adipose tissue triglycerides took place even after 2 months. This finding, made under normal physiological conditions, confirms and extends the results of Hollenberg's incubation studies (1).

These results must be reconciled with the observation that lipolysis and interesterification occur during incubation of fat pads in vitro $(11,12)$. The probable explanation is that the pool of triglycerides derived from re-esterification of the fatty acids in the lipolytic pool is small and not in equilibrium with the bulk triglyceride.

Slow interesterification within the depots probably did occur. Figure 3 shows that the ratio of short-chain to total saturated fatty acids in the [022] glycerides was only relatively constant. The ratio rose from 0.14 at 6 weeks to 0.2 at 15 weeks. The relative constancy of this ratio may not be due entirely to lack of interesterification. Any tendency of this ratio to rise because of interesterification might be offset in part by the more rapid loss from adipose tissue of short-chain saturated acids than long-chain saturated acids.

Whereas triglycerides, after deposit, did not undergo extensive interesterification, some mixing of fatty acids from the two diets did occur before deposit, during the period when dietary coconut oil was replaced with safflower oil. As shown in Figure 3 , at 6 weeks the ratio of short-chain acids to total saturated acids in the [022] glycerides was not zero, but 0.14 . This mixing before deposit could have occurred at several sites: in the intestine, where plasma fatty acids may be incorporated into triglycerides entering the lymph (13); in the liver, where plasma fatty acids are incorporated with dietary fatty acids in lipoprotein triglyceride (14); and in cytoplasm of adipose cells, where newly arriving triglycerides are largely hydrolyzed and re-esterified with new glycerol before deposit (15-20).

In interpreting the changes in the fatty acid composition of depot fat brought about by changes in the diet, the possibility of differential mobilization from adipose tissue must be considered. Figures 3 and 5 show that during the final 9 weeks of the experiment, glycerides containing short-chain saturated acids were more rapidly lost from adipose tissue than glycerides containing long-chain saturated acids. In Hirsch's study of the turnover of fatty acids in human adipose tissue (21), no differences were noted in the rates of mobilization of palmitic, stearic, oleic, and linoleic acids. Human adipose tissue, however, contains only small quantities of lauric and myristic acids. The more rapid disappearance of short-chain glycerides may be related to the properties of the epinephrine-sensitive adipose tissue lipase described by Rizack (22), which in vitro hydrolyzes short-chain saturated glycerides more rapidly than long-chain saturated glycerides. It is also possible to explain the more rapid disappearance of short-chain glycerides from adipose tissue without assuming differential mobilization. If more long-chain than short-chain acids are recycled back to adipose tissue after mobilization, the proportion of short-chain acids in the tissue will decrease.

\section{Summary}

The extent to which triglycerides stored in adipose tissue undergo hydrolysis and re-esterification was investigated. A group of rats was fed a series of oils of widely different fatty acid compositions. The triglycerides of adipose tissue were then separated according to their degree of unsaturation by chromatography on silicic acid impregnated with silver nitrate. By this procedure, it was possible to detect triglycerides that could have been formed only by interesterification of the different dietary fats in adipose depots. Little interesterification occurred during a 9-week period. It is concluded that most triglyceride molecules in adipose depots are stored intact until mobilized.

Triglycerides containing short-chain saturated acids (lauric and myristic) were mobilized more rapidly from adipose tissue than were glycerides containing long-chain saturated acids.

\section{References}

1. Hollenberg, C. H. Transfer of fatty acids between triglyceride species in rat adipose tissue. J. Lipid Res. 1965, 6, 84. 
2. Stein, Y., and O. Stein. Metabolic activity of rat epididymal fat pad labeled selectively by an in vivo incubation technique. Biochim. biophys. Acta (Amst.) 1961, 54, 555.

3. Barrett, C. B., M. S. J. Dallas, and F. B. Padley. The separation of glycerides by thin-layer chromatography on silica impregnated with silver nitrate. Chem. Industr. 1962, 1050.

4. Kaufmann, H. P., and H. Wessels. Die Dünnschicht-Chromatographie auf dem Fettgebiet XIV: Die Trennung der Triglyceride durch Kombination der Adsorptions- und der Umkehrphasen-Chromatographie. Fette-Seifen-Anstrichmittel 1964, 66, 81.

5. Stoffel, W., F. Chu, and E. H. Ahrens, Jr. Analysis of long-chain fatty acids by gas-liquid chromatography: micromethod for preparation of methyl esters. Analyt. Chem. 1959, 31, 307.

6. Mattson, F. H., and R. A. Volpenhein. The use of pancreatic lipase for determining the distribution of fatty acids in partial and complete glycerides. J. Lipid Res. 1961, 2, 58.

7. Luddy, F. E., R. A. Barford, S. F. Herb, P. Magidman, and R. W. Riemenschneider. Pancreatic lipase hydrolysis of triglycerides by a semimicro technique. J. Amer. Oil Chem. Soc. 1964, 41, 693.

8. Gellhorn, A., W. Benjamin, and M. Wagner. The in vitro incorporation of acetate-1-C $\mathrm{C}^{14}$ into individual fatty acids of adipose tissue from young and old rats. J. Lipid Res. 1962, 3, 314.

9. Vander Wal, R. J. Calculation of the distribution of saturated and unsaturated acyl groups in fats, from pancreatic lipase hydrolysis data. J. Amer. Oil Chem. Soc. 1960, 37, 18.

10. Longenecker, H. E. Deposition and utilization of fatty acids of low molecular weight; and a fatty acid analysis of coconut oil. J. biol. Chem. 1939, 130, 167.

11. Dole, V. P. The fatty acid pool in adipose tissue. J. biol. Chem. 1961, 236, 3121.
12. Gorin, E., and E. Shafrir. Turnover of adipose tissue triglycerides measured by the rates of synthesis and release of triglyceride-glycerol. Biochim. biophys. Acta (Amst.) 1963, 70, 109.

13. Havel, R. J., and A. Goldfien. The role of the liver and of extrahepatic tissues in the transport and metabolism of fatty acids and triglycerides in the dog. J. Lipid Res. 1961, 2, 389.

14. Bragdon, J. H., and A. Karmen. Effect of ingested fat on fatty acid composition of serum lipoproteins. J. Lipid Res. 1961, 2, 400.

15. Borgstrom, B., and P. Jordan. Metabolism of chylomicron glyceride as studied by $\mathrm{C}^{14}$-glycerol- $\mathrm{C}^{14}$ palmitic acid labeled chylomicrons. Acta. Soc. Med. upsalien. 1959, 64, 185.

16. Reiser, R., M. C. Williams, and M. F. Sorrels. The transport and dynamic state of exogenous glyceroland palmitic acid-labeled tripalmitin. J. Lipid Res. 1960, 1, 241.

17. Rodbell, M. The removal and metabolism of chylomicrons by adipose tissue in vitro. J. biol. Chem. 1960, 235, 1613.

18. Olivecrona, T. Metabolism of chylomicrons labeled with $\mathrm{C}^{\mathbf{1 4}}$-glycerol-H ${ }^{\mathbf{3}}$-palmitic acid in the rat. $\mathrm{J}$. Lipid Res. 1962, 3, 439.

19. Rodbell, M., and R. O. Scow. Metabolism of chylomicrons and triglyceride emulsions by perfused rat adipose tissue. Amer. J. Physiol. 1965, 208, 106.

20. Markscheid, L., and E. Shafrir. Incorporation of lipoprotein-borne triglycerides by adipose tissue in vitro. J. Lipid Res. 1965, 6, 247.

21. Hirsch, J. Fatty acid patterns in human adipose tissue in Adipose Tissue, A. E. Renold and G. F. Cahill, Jr., Eds. Washington D. C., American Physiological Society, 1965, p. 181.

22. Rizack, M. A. An epinephrine sensitive lipolytic activity in adipose tissue. J. biol. Chem. 1961, 236, 657. 